\title{
KAJIAN FAKTOR SUKSES IMPLEMENTASI E-GOVERNMENT STUDI KASUS: PEMERINTAH KOTA BOGOR
}

\author{
Darmawan Napitupulu \\ Laboratorium E-Government, Fakultas Ilmu Komputer, Universitas Indonesia \\ Depok, Jawa Barat 16424 \\ Email: darwan.na70@gmail.com
}

\begin{abstract}
This article aims to describe the picture of the successful implementation of e-Government in Indonesia, particularly in the city of Bogor. Bogor city has made e-Government initiatives since 2008 and has won numerous awards related to the implementation of e-Government until now. Therefore, Bogor city can be a reference for other regions in implementing e-government. The method used in this study was a questionnaire-based survey that lists the success factors of the results of previous studies. Respondents are employees who work in the office of the city of Bogor Kominfo many as 16 people in particular are associated with the development of e-Government system. The results showed that of the 55 success factors asked kesetujuannya level, there are only 50 success factors memenui testing criteria. Thus 50 success factors must be the priority and focus for other local government to support the successful implementation of e-Government.
\end{abstract}

\section{Abstrak}

Artikel ini bertujuan untuk mendeskripsikan gambaran keberhasilan implementasi eGovernment di Indonesia khususnya di kota Bogor. Kota Bogor telah melakukan inisiatif e-Government sejak 2008 dan telah berhasil meraih berbagai penghargaan terkait implementasi e-Government hingga sekarang. Oleh karena itu kota Bogor dapat menjadi rujukan bagi daerah lainnya dalam menerapkan eGovernment. Metode yang digunakan dalam penelitian ini adalah survei berbasiskan kuesioner yang berisi daftar faktor sukses dari hasil penelitian sebelumnya. Responden merupakan pegawai yang bekerja di kantor kominfo kota Bogor sebanyak 16 orang khususnya yang terkait dengan pengembangan sistem eGovernment. Hasil penelitian menunjukkan dari 55 faktor sukses yang ditanyakan tingkat kesetujuannya, hanya ada 50 faktor sukses yang memenui kriteria pengujian. Dengan demikian 50 faktor sukses tersebut harus menjadi prioritas dan fokus bagi Pemerintah daerah lainnya untuk mendukung kesuksesan implementasi e-Government.

Kata Kunci: e-government, faktor sukses, implementasi, bogor.

\section{PENDAHULUAN}

Perkembangan teknologi informasi dan komunikasi (TIK) yang sedemikian pesat telah mempengaruhi kehidupan manusia, terutama mengubah karakteristik hubungan dengan manusia, bisnis, bahkan dengan pemerintah (Walid, 2003). Kehadiran Teknologi Informasi dan Komunikasi (TIK) telah mengubah cara interaksi antara pemerintah dengan masyarakat dan hal ini telah membawa pada pengembangan fenomena baru yang disebut dengan eGovernment. Saat ini dunia sedang menuju era masyarakat informasi dimana kebutuhan dan tuntutanakan informasi menjadi sangat tinggi untuk diakses, dikelola dan didayagunakan dalam volume yang besar secara cepat dan akurat. Hal ini yang mendorong pemerintah untuk memberikan pelayanan yang lebih baik dan transparansi bagi masyarakat dengan memanfaatkan kemajuan Teknologi Informasi dan Komunikasi (TIK). Untuk menjawab tantangan tersebut, pemerintah harus segera melaksanakan proses transformasi menuju egovernment. Melalui proses transformasi tersebut, pemerintah dapat mengoptimasikan pemanfaatan kemajuan teknologi informasi untuk mengeliminasi sekat-sekat organisasi birokrasi, serta membentuk jaringan sistem manajemen dan proses kerja yang memungkinkan instansiinstansi pemerintah bekerja secara terpadu untuk menyederhanakan akses ke semua informasi dan layanan publik yang harus disediakan oleh pemerintah. Dengan demikian seluruh lembagalembaga negara, masyarakat, dunia usaha, dan pihak-pihak berkepentingan lainnya dapat setiap saat memanfaatkan informasi dan layanan pemerintah secara optimal (Inpres No.3 2003). Berdasarkan World Bank (2009), e-Government didefinisikan sebagai pemanfaatan Teknologi Informasi oleh lembaga pemerintah seperti WAN, internet, mobile computing yang memiliki 
kemampuan untuk mentransformasi hubungan dengan masyarakat, bisnis dan lembaga pemerintah yang lainnya (AlShehry, dkk., 2010). Pemerintah menggunakan Teknologi Informasi dan Komunikasi (TIK) dalam proses pemerintahan untuk meningkatkan efisiensi, efektifitas, transparansi dan akuntabilitas penyelenggaraan pemerintahan. Teknologi informasi dan komunikasi (TIK) yang modern seperti internet, mobile communication, wireless devices dan kombinasi teknologi yang lain digunakan untuk mengimplementasikan solusi eGovernment. Adapun dua ciri atau kriteria utama yang harus terdapat pada sistem e-Government yakni ketersediaan (availability) dan aksesibilitas (accessibility) (Sami, 2012). Pertama, layanan dan transaksi e-Government harus tersedia 24 jam sehari, 7 hari seminggu (non-stop). Pengguna bebas memilih kapan saja yang bersangkutan ingin berhubungan dengan pemerintah untuk melakukan berbagai transaksi atau mekanisme interaksi. Hal ini memungkinkan masyarakat dan pelaku bisnis dengan fleksibilitas untuk mengakses layanan diluar jam kerja pemerintah. Yang kedua, eGovernment sangat tergantung pada aksesibilitas layanan yang tersedia pada website. Jika layanan tersebut tidak dapat diakses maka dapat dikatakan e-Government tidak berhasil atau akan mengalami kegagalan. Berdasarkan Inpres No.3 Tahun 2003 bahwa inisiatif e-Government telah dilakukan oleh banyak instansi pemerintah pusat dan daerah dalam mengembangkan pelayanan publik melalui jaringan komunikasi dan informasi. Namun dari hasil pengamatan yang dilakukan oleh Kementrian Komunikasi dan Informasi, sebagaian besar institusi pemerintah baru berada pada tahap awal pengembangan eGovernment yakni pembuatan situs informasi. Dengan kata lain, pengembangan e-Government di Indonesia dapat dikatakan masih jauh dari yang diharapkan. Hal ini ditunjukkan lagi dengan kondisi rendahnya tingkat aksesibilitas situs web pemerintah dimana berdasarkan penelitian Kementrian Komunikasi dan Informasi (2004) bahwa dari 224 situs web pemerintah di tahun 2004 terdapat $10 \%$ web tidak dapat dibuka (Depkominfo, 2004). Ditambah lagi penelitian Hendriawan (2008) yang melaporkanbahwa dari 402 situs web di tingkat Pemda, terdapat 65 situs yang tidak dapat diakses, atau $16 \%$ dari total situs yang ada (Hendriawan, 2008). Bahkan berdasarkan hasil survei nasional oleh Kementrian Komunikasi dan Informasi berupa Pemeringkatan e-Government di Indonesia (PeGI) tahun 2012, hanya ada 6 pemerintah daerah dari total 497 kabupaten/kota (berdasarkan data Ditjen Otda Kemdagri 2012) yang dianggap berhasil mengimplementasikan eGovernment sedangkan di tingkat propinsi, implementasi e-Government masih mendapatkan nilai kurang (Depdagri, 2009). Jika Indonesia dibandingkan negara lain dalam hal adopsi eGovernment berdasarkan survei internasional Waseda e-Government ranking 2012, ternyata Indonesia jauh tertinggal dan berada pada peringkat 33 dari 55 negara pengadopsi eGovernment. Bahkan di tahun 2013, Indonesia turun ke peringkat 40 dari 55 negara yang disurvei. Senada dengan hal tersebut, hasil pemeringkatan e-Government oleh United Nations 2012 menunjukkan Indonesia berada pada peringkat 7 dari total 11 negara ASEAN, jauh di bawah Malaysia dan Vietnam. Berangkat dari kondisi yang dikemukakan, dapat dikatakan bahwa penerapan e-Government di Indonesia belumlah optimal dan mengindikasikan hanya sekedar pemenuhan terhadap kebijakan tersebut tanpa disertai dengan kualitas. Namun tidak dapat dipungkiri, ada beberapa daerah yang memiliki inisiatif dan berhasil menerapkan eGovernment. Oleh karena itu dalam penelitian ini akan dipaparkan faktor-faktor yang mempengaruhi keberhasilan khususnya dalam penerapan e-Government. Faktor-faktor yang mempengaruhi atau menentukan keberhasilan disebut dengan CSF (Critical Success Factors) (Henny, 2006). Mendefinisikan CSF khususnya pada implementasi e-Government akan membantu organisasi dalam menghindari kegagalan proyek e-Government (Al-Kaabi, 2010). Dengan mengetahui CSF, organisasi dapat fokus pada sejumlah faktor yang dapat menjamin keberhasilan organisasi (Rockhart, 1979).

Obyek yang dijadikan fokus pada penelitian ini adalah Pemerintah kota (Pemkota) Bogor, dengan pertimbangan bahwa Pemkot Bogor merupakan salah satu daerah yang dianggap berhasil mengimplementasikan e-Government. Kota Bogor telah memulai inisiatif eGovernment sejak 2008-2009 jauh sebelum Inpres dikeluarkan serta telah berhasil memperoleh berbagai penghargaan atas keberhasilannya dalam implementasi eGovernment. Pada tahun 2009, Majalah Warta Ekonomi memberikan e-Government award sebagai juara terbaik selain kabupaten Jembrana dan kota Surabaya pada kategori Pemerintah Kabupaten/Kota Pengaplikasi e-Government. Di tahun yang sama, kota Bogor juga meraih penghargaan dari Universitas Gunadarma sebagai juara II pada kategori Website Terbaik Tingkat II se Indonesia (Junaidi, 2011). Pada tahun 2011, Bogor memperoleh penghargaan ICT Pura dari Kementrian Komunikasi dan Informatika tingkat nasional dimana kota Bogor terpilih menjadi yang terbaik dari 5 kota di wilayah propinsi Jawa Barat dan mendapat predikat madya tingkat nasionalserta dianggap 
sebagai kota yang telah siap menghadapi era ekonomi digital. Selain itu pada tahun 2013, kota Bogor juga memperoleh penghargaan IDSA (Indonesia Digital Society Award) sebagai Silver Champion untuk kategori Community dan tahun 2014 Bogor berhasil meraih juara runner-up satu dalam penghargaan IDSA 2014 untuk kategori Pemerintah kota. Oleh karena itu dalam penelitian ini kota Bogor dapat dijadikan rujukan bagi lembaga pemerintah lain dalam proses implementasie-Government.

\subsection{Potret Pengembangan E-Government Kota Bogor}

Seperti telah disebutkan sebelumnya, Kota Bogor telah memulai inisiatif e-Government sejak 2008-2009 dan meraih beragam penghargaan atas keberhasilannya dalam menerapkan e-Government khususnya tingkat kabupaten/kota di Indonesia. Berbagai terobosan dan inovasi yang dilakukan seperti membangun infrastruktur jaringan intranet dan internet SKPD dan Kelurahan se-Kota Bogor, mengimplementasikan e-procurement Kota Bogor, mengintegrasikan POS PBB (Payment Online System Pajak Bumi dan Bangunan), mengintegrasikan SIAK Online Kota Bogor hingga mengimplementasikan aplikasi Kantaya. Pengembangan Infrastruktur jaringan internet Pemkot Bogor yang telah mencapai 40 Mbps sehingga meningkatkan kecepatan jaringan internet di Pemerintah Kota Bogor. Selain itu pemeliharaan dan peningkatan back bone sebanyak 18 BTS yang mencakup kelurahan dan seluruh SKPD di Kota Bogor dengan jaringan Fiber Optik (FO) di 20 titik merupakan upaya peningkatan kualitas sambungan internet dan intranet di Kota Bogor. Disamping infrastruktur, pengembangan aplikasi e-Government seperti SIM Kantaya, Kepegawaian, Arsip, Perpustakaan, Surat, Pembangunan Daerah serta aplikasi lain pendukung pemerintahan sehingga tercapai birokrasi yang efektif dan efisien. Terjaminnya keberlangsungan Website dan Webmail www.kotabogor.ac.id sehingga masyarakat dapat mengakses informasi pada Website secara online dan telah dimuat dalam berita sebanyak 5915 judul dengan tingkat kunjungan hingga akhir tahun 2013 mencapai 12 juta kunjungan (Kantor Komunikasi dan Informatika Kota Bogor, 2013).

Tidak ketinggalan penerapan e-procurement untuk pengadaan barang dan jasa, yaitu proses tender atau lelang proyek melalui sistem internet dimana hal ini ternyata mampu mengurangi proses KKN yang kerap terjadi dalam proses tender. Manfaat lainnya adalah efisiensi anggaran sekitar $15 \%$ kembali ke kas daerah dan penyedia barang dan jasa dapat mengurangi biaya transportasi karena mereka dapat mendaftar sebagai peserta tender tanpa harus datang langsung ke kantor pemda. Program unggulan e-government Pemerintah Kota Bogor lainnya adalah Kantaya, yaitu semacam e-office yang akan meningkatkan interaksi antar instansi dengan cepat dan akurat, serta memberikan kualitas layanan publik yang akuntabel dan transparan. Pentingnya partisipasi masyarakat juga dinilai penting sebagaimana terlihat dengan terbentuknya komunitas berbasis online berupa jaringan oline RT-RW.

Dalam implementasi e-government, Pemerintah Kota Bogor bekerjasama dengan BPPT untuk pengkajian, penerapan, dan pemasyarakatan teknologi untuk mendukung pembangunan daerah Kota Bogor. Dengan adanya kerjasama tersebut, diharapkan Pemerintah Kota Bogor bisa memiliki sebuah jaringan informasi yang berbasis teknologi dan terpadu, mencakup bidang kerja seperti kepegawaian, kesehatan, pendidikan sampai bidang arsip dan perpustakaan, demikian juga dalam bidang pelayanan perijinan dan berbagai pelayanan langsung kepada masyarakat. Melalui pengembangan e-government, maka masyarakat akan lebih mudah berhubungan dengan Pemerintah Kota Bogor, baik pada saat membutuhkan informasi atau pada saat mereka membutuhkan pelayanan untuk melancarkan kegiatan. Pemda Kota Bogor pun bekerjasama dengan Depkominfo dalam mengimplementasikan migrasi dan penggunaan perangkat lunak legal atau free open source software dan interoperabilitas data. Tidak hanya lembaga pemerintah, pihak swastapun seperti PT. Digital Wireless Indonesia (Diginet) juga menjadi mitra Kota Bogor untuk pemanfaatan tower triangle milik Pemkot Bogor. Kedepannya, Pemkot Bogor ingin mengembangkan e-Government yang terintegrasi sesuai agenda reformasi birokrasi nasional serta pengembangan Kota Bogor sebagai Smart Governance dimana setiap SKPD memiliki sistem informasi baik untuk layanan masyarakat, dunia usaha maupun layanan internal sesuai dengan prioritas kebutuhan secara bertahap. Dari segi infrastruktur, pengembangan data center dan data recovery yang baik untuk menjamin availability dan peningkatan keamanan informasi. Selain itu, pembangunan telekomunikasi internal Pemkot yang berbasis internet (VoIP, Teleconference, dll). Tidak ketinggalan juga peningkatan kuantitas, kapasitas dan kapabilitas SDM di bidang TIK menjadi prioritas pengembangan eGovernment.

\subsection{Penelitian Terkait}

Walaupun implementasi e-Government telah berjalan sejak kehadiran regulasi pemerintah tahun 2003, namun dapat dikatakan bahwa 
implementasi e-Government berjalan lambat. Beberapa daerah menunjukkan inisiatif dan kinerja pengembangan e-Government yang cukup baik, namun beberapa daerah lain baru memahami penerapan e-Government hanyalah sebatas membangun website. Bahkan website yang ada pun jauh dari kesan informatif. Akibat kesalahan pemahaman tersebut, membuat penerapan e-Government di Indonesia mengalami kegagalan (Junaidi, 2011; Supangkat, 2006). Disamping itu masih sedikitnya publikasi, informasi ataupun hasil penelitian dari daerah yang dianggap berhasil dalam menerapkan eGovernment di Indonesia khususnya tentang gambaran keberhasilan daerah tersebut sehingga dapat dijadikan pembelajaran dan rujukan bagi daerah lainnya dalam menerapkan e-Government. Penelitian oleh Furuhold \& Wahid menyebutkan ada 6 faktor penentu keberhasilan (CSF) penerapan e-Government khususnya di Sragen yakni kepemimpinan yang kuat, pelibatan semua pihak, penyiapan sumber daya manusia, implementasi bertahap, pembangunan kemitraan dan evaluasi rutin (Furuholt, 2008). Senada dengan hal tersebut, penelitian sejenis yang dilakukan terhadap 5 daerah diperoleh setidaknya ada 4 faktor dominan yang menjadi pendukung keberhasilan yaitu adanya political will kepala daerah, master plan pengembangan e-Government, manajemen perubahan dan partisipasi masyarakat (Junaidi, 2011). Penelitian terkait faktor keberhasilan di Terong kabupaten Bantul, Propinsi Yogyakarta menegaskan kepemimpinan yang kuat dan good will memegang peranan penting dalam keberhasilan penerapan eGovernment (Dewi, 2011). Selainitu penelitian yang dilakukan oleh Faizah \& Sensuse tentang faktor sukses implementasi e-Government di 4 kabupaten/kota (kabupaten Jembrana, kabupaten Sragen, kota Yogyakarta dan kota Surabaya) menunjukkan ada tiga faktor kunci keberhasilan e-Government yakni kebijakan, kelembagaan dan kepemimpinan (Faizah dkk., 2009). Pada penelitian ini, penulis akan menggunakan hasil penelitian penulis sebelumnya yang telah berhasil mengidentifikasi 54 faktor sukses (CSF) terkait implementasi e-Government yang dapat disajikan pada tabel 1 di bawah (Napitupulu, 2014). Keseluruhan faktor sukses tersebut menjadi variabel dalam penelitian ini untuk menentukan fokus penelitian bagi peneliti dalam mengumpulkan data khususnya terkait faktor sukses implementasi e-Government di Pemkot Bogor.
Tabel 1. Faktor Sukses Implementasi e-Government

\begin{tabular}{|c|c|}
\hline No & Faktor Sukses \\
\hline 1 & Melibatkan Pengguna dan Stakeholder \\
\hline 2 & Perencanaan yang baik \\
\hline 3 & Menggunakan Portal/Aplikasi \\
\hline 4 & Pelatihan \\
\hline 5 & Usabilitas Sistem yang baik \\
\hline 6 & $\begin{array}{l}\text { Kampanye mengenai kegunaan dan } \\
\text { kelebihan sistem }\end{array}$ \\
\hline 7 & Membuat Prototipe \\
\hline 8 & $\begin{array}{l}\text { Skill dan Kepakaran anggota tim yang } \\
\text { baik }\end{array}$ \\
\hline 9 & Kepemimpinan yang kuat \\
\hline 10 & $\begin{array}{l}\text { Koordinasi yang baik diantara orang- } \\
\text { orang yang terlibat di dalam proyek }\end{array}$ \\
\hline 11 & $\begin{array}{l}\text { Mempertimbangkan best practice yang } \\
\text { sudah ada }\end{array}$ \\
\hline 12 & Pembiayaan yang cukup \\
\hline 13 & Membuat bisnis proses yang lebih baik \\
\hline 14 & $\begin{array}{l}\text { Adanya kebijakan pemerintah yang } \\
\text { mendukung }\end{array}$ \\
\hline 15 & Dukungan dan stabilitas politik \\
\hline 16 & Strategi Outsourcing yang baik \\
\hline 17 & $\begin{array}{l}\text { Ketersediaan } \\
\text { infrastruktur/layanan ICT }\end{array}$ \\
\hline 18 & $\begin{array}{l}\text { Komputer/Internet literacy } \\
\text { pengguna/masyarakat }\end{array}$ \\
\hline 19 & Struktur organisasi yang jelas dan baik \\
\hline 20 & Dukungan Internasional \\
\hline 21 & Terjaminnya keamanan sistem \\
\hline 22 & Adanya kerangka hukum \\
\hline 23 & Adanya monitoring dan evaluasi \\
\hline 24 & $\begin{array}{l}\text { Kerjasama yang baik dengan institusi } \\
\text { lain }\end{array}$ \\
\hline 25 & Manajemen perubahan yang tepat \\
\hline 26 & $\begin{array}{l}\text { Lingkungan sosial budaya yang } \\
\text { mendukung }\end{array}$ \\
\hline 27 & Pemodelan sistem yang baik \\
\hline 28 & $\begin{array}{l}\text { Menyesuaikan dengan birokrasi yang } \\
\text { ada }\end{array}$ \\
\hline 29 & Orientasi pada Masyarakat \\
\hline 30 & Dukungan Manajemen tingkat atas \\
\hline 31 & Mendukung interoperabilitas \\
\hline 32 & Manajemen proyek yang baik \\
\hline 33 & $\begin{array}{l}\text { Kualitas informasi yang baik di dalam } \\
\text { sistem }\end{array}$ \\
\hline 34 & Kualitas sistem yang baik \\
\hline 35 & Kualitas layanan yang baik \\
\hline 36 & $\begin{array}{l}\text { Adanya kepercayaan terhadap system } \\
\text { dan government }\end{array}$ \\
\hline 37 & $\begin{array}{l}\text { Adanya Kesadaran dari pemerintah dan } \\
\text { masyarakat }\end{array}$ \\
\hline 38 & $\begin{array}{l}\text { Adanya tata kelola Pemerintahan yang } \\
\text { baik }\end{array}$ \\
\hline 39 & $\begin{array}{l}\text { Memenuhi } \\
\text { pengguna/masyarakat }\end{array}$ \\
\hline 40 & $\begin{array}{l}\text { Adanya metodologi pengembagan } \\
\text { sistem yang tepat }\end{array}$ \\
\hline 41 & $\begin{array}{ll}\text { Adanya } & \text { Pembayaran/Transaksi } \\
\text { Elektronik } & \end{array}$ \\
\hline
\end{tabular}




\begin{tabular}{|c|c|}
\hline No & Faktor Sukses \\
\hline 42 & $\begin{array}{l}\text { Adanya Produk Komersial seperti iklan } \\
\text { dan banner }\end{array}$ \\
\hline 43 & $\begin{array}{l}\text { Implementasi yang dilakukan secara } \\
\text { bertahap }\end{array}$ \\
\hline 44 & $\begin{array}{l}\text { Komponen/Sistem/Sumber Daya dapat } \\
\text { digunakan kembali }\end{array}$ \\
\hline 45 & Peningkatan Berkelanjutan \\
\hline 46 & Kreativitas \& Inovasi \\
\hline 47 & $\begin{array}{l}\text { Kemauan Berubah } \text { Berdasarkan } \\
\text { Perubahan Paradigma }\end{array}$ \\
\hline 48 & Adanya Penghargaan dan Pengakuan \\
\hline 49 & Tingginya Minat Masyarakat \\
\hline 50 & $\begin{array}{l}\text { Peningkatan Penghasilan Asli Daerah } \\
\text { (PAD) }\end{array}$ \\
\hline 51 & $\begin{array}{l}\text { Adanya partisipasi masyarakat dalam } \\
\text { pengambilan kebijakan/keputusan publik }\end{array}$ \\
\hline 52 & $\begin{array}{l}\text { Prioritisasi Pengembangan } \\
\text { Government } \\
\text { (e-Government Prioritization) }\end{array}$ \\
\hline 53 & $\begin{array}{l}\text { Adanya Potensi dan Sinergi Pasar yang } \\
\text { baik }\end{array}$ \\
\hline 54 & $\begin{array}{l}\text { Adanya Tekanan Eksternal yang } \\
\text { mendorong } \\
\text { penerapan e-Gov }\end{array}$ \\
\hline 55 & $\begin{array}{l}\text { Adanya Panduan Pengembangan } \\
\text { Government }\end{array}$ \\
\hline
\end{tabular}

\section{METODOLOGI}

Penelitian yang dilakukan merupakan penelitian deskriptif karena dalam penelitian ini ingin diperoleh gambaran keberhasilan yang konkrit dan mendetail dari daerah yang dianggap berhasil dalam menerapkan e-Government (Neuman 2007). Pendekatan yang digunakan dalam penelitian adalah pendekatan kualitatif dan kuantitatif, dimana 55 faktor sukses yang diperoleh dari penelitian sebelumnya dengan pendekatan kualitatif merupakan hasil dan analisa sintesa dari sejumlah penelitian yang terkait dengan faktor sukses implementasi eGovernment. Dalam hal ini peneliti berupaya menggali lebih dalam dan memahami fenomena yang terjadi khususnya tentang faktor-faktor yang mempengaruhi keberhasilan implementasi e-Government (Napitupulu, 2014; Ellet, dkk., 2002). Pendekatan kuantitatif yang digunakan yakni dengan metode survei berbasiskan kuesioner sebagai alat atau instrumen untuk mengumpulkan data. Dalam hal ini, penelitian bertujuan ingin mengkonfirmasi faktor sukses yang diperoleh sebelumnya dengan kondisi di lapangan dimana obyek penelitian yang dipilih sebagai studi kasus adalah Pemkot Bogor. Pertimbangannya yaitu bahwa Pemkot Bogor merupakan daerah yang dianggap berhasil mengimplementasikan inisiatif e-Government sehingga Pemkot tersebut mengetahui faktorfaktor yang mendukung keberhasilan implementasi e-Government. Pemilihan sampel atau responden dilakukan secara purposive sampling yakni orang-orang yang hanya terkait dengan domain pengembangan Teknologi Informasi dan Komunikasi (TIK) khususnya eGovernment. Total jumlah responden keseluruhan adalah 16 orang yang merupakan karyawan mulai dari staf hingga kepala kantor Kominfo (Komunikasi dan Informasi) Pemerintah Kota Bogor. Kantor Kominfo dibentuk berdasarkan Peraturan Daerah Kota Bogor Nomor 3 tahun 2010 tentang Organisasi Perangkat Daerah, yang terdiri dari Sub Bagian Tata Usaha, Seksi Postel dan Informasi Publik, Seksi Sarana Komunikasi dan Informatika, dan Seksi Aplikasi Telematika dan Pengolah Data Elektronik.

Kuesioner yang digunakan dalam penelitian ini berisi pertanyaan tingkat kesetujuan responden terhadap keseluruhan faktor sukses (CSF) implementasi e-Government yang diperoleh dari hasil penelitian sebelumnya (Napitupulu, 2014) dimana skala yangdipakai adalah skala likert dimana 1 menunjukkan "sangat tidak setuju", 2 = "tidak setuju, 3 = "netral", 4 = "setuju" dan 5 menyatakan "sangat setuju". Dari data yang diperoleh akan diolah dengan statistik deskriptif untuk mencari frekuensi dan nilai rata-rata (Mean) setiap faktor. Dengan mengikuti penelitian Hajiheydari \& Dabaghkashani (2011), suatu faktor dapat digolongkan menjadi faktor sukses (CSF) dalam implementasi e-Government jika nilai rata-rata (Mean) lebih besar atau sama dengan 4 (Dabaghkashani, dkk., 2011).

\section{HASIL DAN PEMBAHASAN}

Setiap faktor sukses yang diperoleh dari hasil penelitian sebelumnya pada tabel 1 di atas memiliki level (degree) yang sama. Tidak ada yang lebih penting ataupun kurang penting namun semua faktor adalah setara satu sama lain. Keseluruhan faktor sukses akan dicocokkan dengan kondisi penerapan e-Government Pemerintah Kota Bogor dimana hanya ada 50 faktor sukses yang memenuhi kriteria dari seluruh faktor sukses yang ada, yang dapat ditunjukkan pada tabel 2 di bawah ini :

Tabel 2. Skor Rata-Rata(Mean) Faktor Sukses Implementasi e-Government

\begin{tabular}{clc}
\hline No & \multicolumn{1}{c}{ Faktor Sukses } & Mean \\
\hline 1 & $\begin{array}{l}\text { Melibatkan Pengguna dan } \\
\text { Stakeholder }\end{array}$ & 4.2500 \\
2 & Perencanaan yang baik & 4.2500 \\
3 & Menggunakan & 4.1250 \\
& Portal/Aplikasi & 4.1875 \\
4 & Pelatihan & 4.2500 \\
5 & Usabilitas Sistem yang baik &
\end{tabular}




\begin{tabular}{|c|c|c|}
\hline No & Faktor Sukses & Mean \\
\hline 6 & $\begin{array}{ll}\text { Kampanye } & \text { mengenai } \\
\text { kegunaan dan kelebihan } \\
\text { sistem }\end{array}$ & 4.1250 \\
\hline 7 & Membuat Prototipe & 4.0625 \\
\hline 8 & $\begin{array}{l}\text { Skill dan Kepakaran anggota } \\
\text { tim yang baik }\end{array}$ & 4.1875 \\
\hline 9 & Kepemimpinan yang kuat & 4.4375 \\
\hline 10 & $\begin{array}{l}\text { Koordinasi yang baik } \\
\text { diantara orang-orang yang } \\
\text { terlibat di dalam proyek }\end{array}$ & 4.1875 \\
\hline 11 & $\begin{array}{l}\text { Mempertimbangkan best } \\
\text { practice yang sudah ada }\end{array}$ & 4.1250 \\
\hline 12 & Pembiayaan yang cukup & 4.3750 \\
\hline 13 & $\begin{array}{l}\text { Membuat bisnis proses yang } \\
\text { lebih baik }\end{array}$ & 4.1875 \\
\hline 14 & $\begin{array}{l}\text { kebijakan pemerintah yang } \\
\text { mendukung }\end{array}$ & 4.2500 \\
\hline 15 & $\begin{array}{l}\text { Dukungan dan stabilitas } \\
\text { politik }\end{array}$ & 4.0625 \\
\hline 16 & $\begin{array}{l}\text { Strategi Outsourcing yang } \\
\text { baik }\end{array}$ & 4.0000 \\
\hline 17 & $\begin{array}{l}\text { Ketersediaan dukungan } \\
\text { infrastruktur/layanan ICT }\end{array}$ & 4.0625 \\
\hline 18 & $\begin{array}{l}\text { Komputer/Internet literacy } \\
\text { dari pengguna/masyarakat }\end{array}$ & 4.2500 \\
\hline 19 & $\begin{array}{l}\text { Struktur organisasi yang } \\
\text { jelas dan baik }\end{array}$ & 4.3750 \\
\hline 20 & Dukungan Internasional & 3.6250 \\
\hline 21 & $\begin{array}{l}\text { Terjaminnya keamanan } \\
\text { sistem }\end{array}$ & 4.4375 \\
\hline 22 & Adanya kerangka hukum & 4.4375 \\
\hline 23 & $\begin{array}{l}\text { Adanya monitoring dan } \\
\text { evaluasi }\end{array}$ & 4.3125 \\
\hline 24 & $\begin{array}{l}\text { Kerjasama yang baik dengan } \\
\text { institusi lain }\end{array}$ & 4.1250 \\
\hline 25 & $\begin{array}{l}\text { Manajemen perubahan yang } \\
\text { tepat }\end{array}$ & 4.0625 \\
\hline 26 & $\begin{array}{l}\text { Lingkungan sosial budaya } \\
\text { yang mendukung }\end{array}$ & 4.1875 \\
\hline 27 & Pemodelan sistem yang baik & 4.1250 \\
\hline 28 & $\begin{array}{ll}\text { Menyesuaikan } & \text { dengan } \\
\text { birokrasi yang ada } & \end{array}$ & 3.6875 \\
\hline 29 & Orientasi pada Masyarakat & 4.1875 \\
\hline 30 & $\begin{array}{l}\text { Dukungan } \\
\text { tingkat atas }\end{array}$ & 4.1875 \\
\hline 31 & Mendukung interoperabilitas & 4.1250 \\
\hline 32 & $\begin{array}{l}\text { Manajemen proyek yang } \\
\text { baik }\end{array}$ & 4.1250 \\
\hline 33 & $\begin{array}{l}\text { Kualitas informasi yang baik } \\
\text { di dalam sistem }\end{array}$ & 4.0625 \\
\hline 34 & Kualitas sistem yang baik & 4.1875 \\
\hline 35 & Kualitas layanan yang baik & 4.3125 \\
\hline 36 & 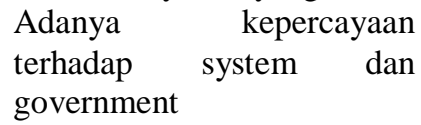 & 4.2500 \\
\hline 37 & $\begin{array}{l}\text { Adanya Kesadaran dari } \\
\text { pemerintah dan masyarakat }\end{array}$ & 4.2500 \\
\hline 39 & $\begin{array}{l}\text { Memenuhi kepuasan } \\
\text { pengguna/masyarakat }\end{array}$ & 4.0625 \\
\hline
\end{tabular}

\begin{tabular}{|c|c|c|}
\hline No & Faktor Sukses & Mean \\
\hline 40 & $\begin{array}{l}\text { Adanya metodologi } \\
\text { pengembagan sistem yang } \\
\text { tepat }\end{array}$ & 4.0625 \\
\hline 41 & $\begin{array}{l}\text { Adanya } \\
\text { Pembayaran/Transaksi } \\
\text { Elektronik }\end{array}$ & 4.1250 \\
\hline 42 & $\begin{array}{l}\text { Adanya Produk Komersial } \\
\text { seperti iklan dan banner }\end{array}$ & 3.7500 \\
\hline 43 & $\begin{array}{l}\text { Implementasi yang } \\
\text { dilakukan secara bertahap }\end{array}$ & 4.3125 \\
\hline 44 & $\begin{array}{l}\text { Komponen/Sistem/Sumber } \\
\text { Daya dapat digunakan } \\
\text { kembali }\end{array}$ & 4.0000 \\
\hline 45 & Peningkatan Berkelanjutan & 4.0625 \\
\hline 46 & Kreativitas \& Inovasi & 4.0625 \\
\hline 47 & $\begin{array}{lr}\text { Kemauan } & \text { Berubah } \\
\text { Berdasarkan } & \text { Perubahan } \\
\text { Paradigma } & \end{array}$ & 4.0000 \\
\hline 48 & $\begin{array}{l}\text { Adanya Penghargaan dan } \\
\text { Pengakuan }\end{array}$ & 4.6250 \\
\hline 49 & \begin{tabular}{l|l} 
Tingginya & Minat \\
Masyarakat &
\end{tabular} & 4.1875 \\
\hline 50 & $\begin{array}{l}\text { Peningkatan Penghasilan } \\
\text { Asli Daerah (PAD) }\end{array}$ & 4.2500 \\
\hline 51 & $\begin{array}{lr}\text { Adanya } & \text { partisipasi } \\
\text { masyarakat } & \text { dalam } \\
\text { pengambilan } & \\
\text { kebijakan/keputusan publik }\end{array}$ & 4.1250 \\
\hline 52 & $\begin{array}{l}\text { Prioritisasi Pengembangan } \\
\text { e-Government } \\
\text { (e-Government } \\
\text { Prioritization) }\end{array}$ & 4.1250 \\
\hline 53 & $\begin{array}{l}\text { Adanya Potensi dan Sinergi } \\
\text { Pasar yang baik }\end{array}$ & 3.5000 \\
\hline 54 & $\begin{array}{l}\text { Adanya Tekanan Eksternal } \\
\text { yang mendorong } \\
\text { penerapan e-Gov }\end{array}$ & 3.8750 \\
\hline 55 & $\begin{array}{lr}\text { Adanya } & \text { Panduan } \\
\text { Pengembangan } & \text { e- } \\
\text { Government } & \\
\end{array}$ & 4.3125 \\
\hline
\end{tabular}

Dari tabel 2 di atas dapat dilihat bahwa faktor sukses "Dukungan Internasional" memiliki nilai rata-rata (Mean) lebih kecil dari 4 yaitu 3.625. Oleh karena itu faktor sukses tersebut tidak memenuhi kriteria dan harus dikeluarkan dari daftar faktor sukses yang final. Demikian juga faktor sukses "Menyesuaikan dengan birokrasi yang ada"juga memiliki nilai rata-rata (Mean) lebih kecil dari 4 yakni sebesar 3.6875, faktor sukses "Adanya Produk Komersial seperti iklan dan banner" yang mempunyai Mean 3.75, faktor sukses "Adanya Potensi dan Sinergi Pasar yang baik" dengan Mean sebesar 3.50 serta faktor sukses "Adanya Tekanan Eksternal yang mendorong penerapan e-Gov" yang mempunyai Mean 3.875 dikeluarkan dari daftar faktor sukses final. Dengan demikian tersisa hanya 50 faktor sukses (CSF) yang menjadi faktor pendukung 
keberhasilan implementasi e-Government khususnya di Pemerintah Kota Bogor. Keseluruan faktor sukses tersebut menjadi gambaran keberhasilan dan menjadi masukan bagi Pemerintah daerah lainnya dalam proses pengembangan e-Government.

\section{KESIMPULAN DAN SARAN}

Dari hasil penelitian yang telah dilakukan dapat ditarik beberapa kesimpulan yaitu:

1. Mendefinisikan CSF khususnya pada implementasi e-Government akan membantu organisasi dalam menghindari kegagalan proyek e-Government

2. Kota Bogor merupakan daerah yang dianggap berhasil menerapkan e-Government melalui berbagai terobosan dan inovasi dan telah meraih berbagai penghargaan dari Warta Ekonomi, ICT Pura, IDSA, dll. Oleh karena itu kota Bogor layak dijadikan rujukan bagi institusi pemerintah lain dalam proses penerapan e-Government

3. Terdapat 50 faktor sukses (CSF) final yang dapat diakomodasi oleh pemerintah dan pihak terkait agar implementasi e-Government terhindar dari kegagalan.

Saran yang dapat diberikan untuk penelitian selanjutnya adalah:

1. Keseluruhan faktor sukses tersebut perlu dinilai oleh pakar melalui expert judgment untuk memperoleh faktor sukses yang valid

2. Penelitian hanya terfokus di kota Bogor saja, sehingga dapat dilakukan penelitian serupa di berbagai kota atau daerah yang lain

\section{DAFTAR RUJUKAN}

Al-Kaabi, R., 2010. Critical success factors ofegovernment: A proposal model for eGovernment implementation in Kingdom of Bahrain. Proceeding of the 6th International Conference one-Government (ICEG), pp: $1-9$.

AlShehry M, Drew S., 2010. E-Government Fundamentals, IADIS International Conference ICT Society and Human Beings

Ambar Sari Dewi, 2011, The Role of Local eGovernment in Bureaucratic Reform in Terong, Bantul District, Internetworking Indonesia Journal, Vol. 3, No. 2, 49-56 Yogyakarta Province, Indonesia

Darmawan Napitupulu, 2014. The Critical Success Factors Study for e-Government Implementation, International Journal of Computer Application, Vol 89, No. 16, March 2014

Deliza Henny, 2006, Tinjauan Penggunaan CSF dan Audit Grid Dalam Analisis Aplikasi
Sistem Informasi, Jurnal Akuntansi, Vol. 6, No. 2, 205-212

Depdagri, 2009, Pemeringkatan e-Government di Indonesia, Diakses dari www.depdagri.go.id

Depkominfo. Kondisi Situs Web Pemerintah Daerah, 2004. Diakses dari http://www.depkominfo.go.id

Ellet M L C., \& Beausang C C., 2002, Introduction to Qualitative Research, "Gastroenterology Nursing", Vol. 25, No.1, pp. 10-14

Faizah N., Dana Indra S, 2009. Faktor-Faktor Sukses Ilmplementasi e-Government di Empat Kabupaten/Kota di Indonesia, Digital Information \& System Conference

Furuholt, B. and Wahid, F., 2008. EGovernment Challenges and The Role of Political Leadership in Indonesia : the case of Sragen, Proceeding of the 41th International Conference on System Sciences

Hajiheydari N \& Dabaghkashani Z, 2011, BPM Implementation Critical Success Factors : Applying Meta-synthesis Approach, International Conference on Social Science and Humanity IPEDR, Vol. 5, pp. 38-43

Hendriawan, 2008. Content Analysis Situs Web Pemerintah Daerah, Tesis Fakultas Ilmu Komputer Universitas Indonesia Business Review 57, 2.

Inpres No.3 2003. Kebijakan dan Strategi Nasional Pengembangan e-Government. http://www.apjii.or.id/v2/upload/Regulasi/I nPresRI3Th2003.pdf Diakses 30 Agustus 2014

Junaidi, 2011, Dukungan E-Government Dalam Upaya Peningkatan Kualitas Elayanan Publik Di Era Otonomi Daerah : Kasus Best Practices Dari Sejumlah Daerah Di Indonesia, Proceeding Simposium Nasional Otonomi Daerah, LAB-ANE FISIP Untirta

Kota Bogor raih penghargaan ICT Pura, www.kominfo.kotabogor.go.id, Diakses: 15 Desember 2014

Kota Bogor raih penghargaan Indonesia Digital Society Award, www.kominfo.kotabogor.go.id, Diakses : 15 Desember 2014

Kantor Komunikasi dan Informatika Kota Bogor. 2013, Pelaksanaan Urusan Komunikasi dan Informatika 2009-2013 serta Rencana 2014-2018,

Kota Bogor raih e-Government Award 2009, www.kotabogor.go.id, Diakses : 15 Desember 2014

Neuman W L., 2007, Basic of Social Research Qualitative and Quantitative Approaches, 
Wisconsin-Whitewater, USA : Pearson Education, Inc

Sami M.,\& Mohd M., 2012, Best Practices in E government: A review of Some Innovative Models Proposed in Different Countries, International Journal of Electrical \& Computer Sciences IJECS-IJENS, Vol. 12 No. 01, Februari 2012

Suhono H. Supangkat, 2006. Framework Strategi Implementasi e-Government. Prosiding
Konferensi Nasional Teknologi Informasi \& Komunikasi Indonesia, ITB

Rockhart, John F., 1979 "Chief Executives Define Their Own Data Needs." Harvard

Walid, Q \& Khaled A., 2003, Understanding Factor Influencing e-Government in Saudi Arabia, International Journal of Computer Application, Vol. 81, No. 2, November 2013 